\title{
Ortolan Buntings Emberiza hortulana mimicking other species and other dialects of own species
}

\author{
Tomasz S. Osiejuk, Katarzyna Ratyńska, Svein Dale, \\ Øyvind Steifetten \& Jakub P. Cygan
}

Osiejuk, T.S., Ratyńska, K., Dale, S., Steifetten, Ø. \& Cygan, J.P. 2004. Ortolan Buntings Emberiza hortulana mimicking other species and other dialects of own species. - Ornis Norvegica 27: 73-79.

We present new acoustically well-documented observations of Ortolan Bunting males from Norway, singing atypical songs with syllables copied from other species and from non-neighbouring, distant populations of own species. The first case concerns a male singing strophes containing syllables of Yellowhammer and Ortolan Bunting, both most probably copied in central Europe. These songs often had broken syntax. The second case concerns a male that sang both typical strophes and strophes that had the initial part copied from a local dialect of Redwing, but with a typical syntax for the species. That male mated successfully. Causes and consequences of vocal mimicry in the species are discussed.

Tomasz S. Osiejuk, Department of Behavioural Ecology, Umultowska 89, PL-61-614, Poznań, Poland. E-mail: osiejuk@amu.edu.pl.Katarzyna Ratyńska,Department of Behavioural Ecology, Umultowska 89, PL-61-614, Poznań, Poland. Svein Dale, Department of Ecology and Natural Resources Management, Agricultural University of Norway, P.O.Box 5003, NO-1432 As, Norway. Øyvind Steifetten, Department of Ecology and Natural Resources Management, Agricultural University of Norway, P.O.Box 5003, NO-1432 Ås, Norway. Jakub P. Cygan, Museum and Institute of Zoology, Polish Academy of Sciences, Wilcza 64, PL-00-679 Warszawa, Poland.

\section{INTRODUCTION}

Studying atypical behaviour of animals often gives an unique opportunity to better understand why and how typical behaviours develop and function. For example, in the case of bird song, some crucial information on song development was gathered thanks to the neurobiological experiments disturbing auditory feedback started by Konishi $(1963,1964)$. Species recognition by song were revealed through the experiments with artificial synthetic songs, which were initiated by Bremond (1968, 1976). Well-documented observations of such peculiarities as interspecific mixed song (vocal mimicry) could be treated as natural experiments, which could shed light on song development and functions fulfilled in natural conditions (Baylis 1982).

In this paper we present evidence of Ortolan Bunting Emberiza hortulana males singing atypical song strophes of very interesting acoustic design and descent (i.e. from whom they were learned) of particular song elements. We also discuss shortly relationships between song design (syllable content, syntax) and functionality, and the potential influence of vocal mimicry on population repertoire. 


\section{RESULTS AND DISCUSSION}

\section{Case 1}

An atypically singing Ortolan Bunting was recorded on 17th May 2003 at Sandmoen forest clear-cut (county Hedmark, Norway, 60 $34^{\prime} \mathrm{N}$, $\left.11^{\circ} 59^{\prime} \mathrm{E}\right)$. For more details about the studied population and its song, see Dale \& Hagen (1997), Dale (2000, 2001 a, b), Dale \& Olsen (2001), Osiejuk et al. (2003a, b) and Osiejuk et al. (2004). The male was recorded three times between 8:00 and 9:00 a.m. with an HHB PDR 1000 Portadat Professional DAT recorder coupled with a Telinga V Sciences DAT microphone. In total, 152 song strophes were recorded during 25 min and $28 \mathrm{~s}$. Such a sample is usually sufficient to contain the full repertoire of normally singing Ortolan Buntings (Osiejuk et al. 2003a).

The male was observed a few days earlier by $\emptyset \mathrm{S}$, who recognised that this Ortolan Bunting with typical plumage sang songs resembling those of Yellowhammer (Emberiza citrinella). The male sang with a mean rate of 6.0 strophes $/ \mathrm{min}$ (range 5.2-6.3), which is typical for the studied population (Osiejuk et al. 2003a).

The syllable repertoire of the male consisted of five units, which formed five different combinations, further called song types (Fig. 1; see Osiejuk et al. 2003a for full bioacoustics nomenclature of the species). These types occurred in altogether eight versions, which differ only in number of syllables, not in their contents or order in sequence. However, the dominating variants belonged to a single song type $j 1 b k l$ (95\% of strophes recorded; Table 1).

The song repertoire of this male was particularly strange, as it combined both sound elements from another species (Yellowhammer) and own species, and in both cases from geographically distant populations. Among five different syllables recorded, only $b$ and $h$ syllables were typical and very common in the Norwegian population (Osiejuk et al. 2003a). All the other elements were never recorded earlier in spite
Bunting (Cramp \& Perrins 1994). Moreover, the combination of whistles $b k l$ is similar to the terminal part of Yellowhammer song, but not to Yellowhammers from Norway. Norwegian Yellowhammers sing a dialect called zii-tyy, which is characterised by a high-pitched and short first whistle, followed by a low-pitched and longer second whistle (Cramp \& Perrins 1994; see Osiejuk et al. 2003b for sonogram). The composition $b k l$ sung frequently by the male from Sandmoen, resembled the whistle composition of Yellowhammer song types, which was relatively rare in Denmark (Hansen 1985) and quite common near Dresden in Germany (Frauendorfer 1994, Frauendorfer unpubl. data).

Song type $h \mathrm{ml}$ fits the syntax rules of the Norwegian Ortolan Bunting population and has the initial series built of typical $h$ syllables. However, this song also sounded slightly different in comparison to typical Norwegian strophes. In fact, $m l$ syllables have never been recorded in Norway, but resembled the final part of some Ortolan Bunting songs from south Germany (Northern Bavaria, Niedersachsen), Austria (Burgenland), but also western and eastern Poland (Conrads 1994, Helb 1997, Osiejuk 2000, Rainer Jahn pers. comm.).

During the first observation the focal male was in aggressive interaction with his male neighbour, including also some counter-singing. However, the song contest might have been a direct effect of close encounters, and not of the song itself. We did not observe any response of a neighbouring Ortolan Bunting later, but the neighbouring male paired quickly, and was very shy and quiet during the rest of the season. The atypically singing male aggressively reacted to the song of a Yellowhammer inhabiting this area and seemed to follow his songs as in typical countersinging (Rutkowska-Guz \& Osiejuk 2004). We observed a single aggressive chase between these birds during the hour of observation, but we are not sure which male initiated the chase. Aggressive interactions between Yellowhammers 
Table 1. Frequency of song types and song variants within sampled recordings of an atypical Ortolan Bunting male from Sandmoen. Note that each letter (or letter with number) separated by space indicates a syllable that is different from all the others found within the studied population. Song types are recognised by composition and order of syllables in a sequence. The number of syllables in a sequence within the song type may differ, as for the j1 b kl type presented here. For more details refer to Osiejuk et al. (2003a).

\section{Song type Song variant $\quad$ Frequency Percent}

Total
$b k 1$
$h$
$h m 1$
$j 1 \mathrm{~b}$
jl $b \begin{array}{lll} & k & 1\end{array}$

\section{$b k l k l$}

$h h h h h h$

$h \mathrm{hhhml} \mathrm{ml} \mathrm{ml} \mathrm{ml} \mathrm{ml} \mathrm{ml} \mathrm{ml} \mathrm{ml}$

jl j1 j1 j1 j1 j1 j1 b

jl $j 1$ jl $b$ kl

j1 $\mathrm{j} 1 \mathrm{j} 1 \mathrm{j} 1 \mathrm{jl} \mathrm{b} \mathrm{kl}$

j1 j 1 j1 j1 j1 j1 b kl

jl j1 j1 j1 j1 j1 jl b kl

\section{1}

1

1

2

1

19

120

7

152
0.7

0.7

0.7

1.3

0.7

12.5

78.9

4.6

100.0 and Ortolan Buntings (both typically singing) are not exceptional (Åke Berg pers. comm., own unpubl. data).

The male from Sandmoen did not attract any female but this year only $53 \%$ of the male population were successful in attracting a female (SD and ØS unpubl. data). The male continued to sing yellowhammer-like songs until mid-June and was suspected of having made a trip up to Starmoen $(>15 \mathrm{~km})$ because a male with yellowhammer-song and some similar rings was seen there one day. It is worth noting that the studied population is rather small (ca. 150 males) and all habitats suitable for Ortolan Buntings were intensively surveyed in that area throughout May and June. As the male from Sandmoen was not ringed as a nestling we do not know whether it originated from Norway. On the other hand, male birds (including Ortolan Bunting) disperse over shorter distances than females, and usually establish territories close to where they were born (Greenwood \& Harvey 1982, Dale 2001b, but compare Stolt 1996). It is also unlikely that he learned $b$ and $h$ syllables outside Fennoscandia as only there such syllables have been recorded (Åström \& Stolt 1993, Osiejuk et al. 2003a). So most probably, he was a young male (in the second calendar year of life), which did not finish learning during his first months of life in Norway. Members of the family Emberizidae regularly imitate songs of other species (see Osiejuk et al. 2003b for small review), but mimicry in Ortolan Buntings seems to be rare, as up to now, we have only had three cases of mimicking males after three years of study and ca. 200 males recorded (Osiejuk 2003a, b, unpubl. data).

This study gives insight into Ortolan Bunting's potential to acquire elements of foreign songs and ability to compose song strophes from partly foreign elements. The species can accurately copy foreign song elements, including the acoustic shape of syllables and temporal organisation (Osiejuk et al. 2003b). Moreover, the recorded song output was dominated by strophes that despite the foreign origin of syllables were organised syntactically in a typical way for the species, i.e. followed the rule of decreasing bandwidth and minimal frequency in subsequent phrases within the song (Osiejuk et al. 2003a, Osiejuk et al. 2004). We may suspect that syntax rules are under genetic control more than are syllable structure in this species. When syllables 
Song types

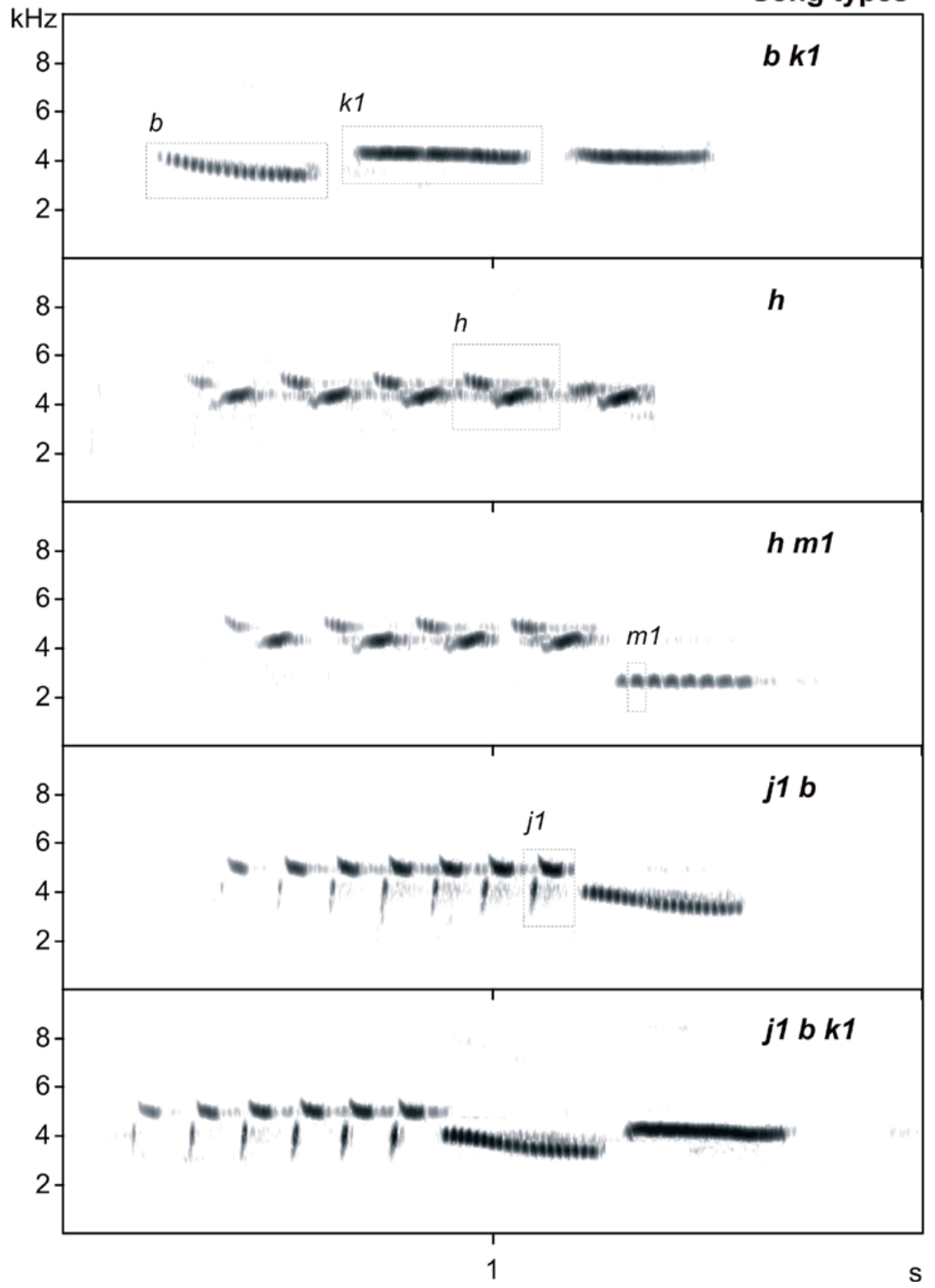

Figure 1. Sonograms of all song types of an atypically singing Ortolan Bunting male from Sandmoen, Norway. Rectangles indicate different syllables from the repertoire. 
are learned from tutors, particular bird species have some intrinsic predisposition for copying particular notes (Baptista 1996). Therefore we have so many mixed singers among sibling species because their songs are similar in acoustic character (Osiejuk \& Kuczyński 2000). On the other hand, this example shows that syntax rules are not sufficient to communicate within a species if the acoustic templates available during the memorization phase were wrong. In other words, song of species specific syntax but structured of foreign elements may not elicit response of conspecifics.

The male from Sandmoen is also interesting because it shows how much the learning process can be disturbed under natural conditions by random factors. One may suspect that our male failed to finish acquisition of speciesspecific songs in the first year of life. There may be many reasons why the memorization phase was not finished, e.g. late brood, paucity of acoustic templates in an isolated population, etc. Anyway, the male from Sandmoen may have tried to complete the learning process during his way home after wintering in Africa, most probably he learning songs from Ortolan Bunting and Yellowhammer males somewhere in Germany, Poland or Denmark.

\section{Case 2}

During five seasons between 1999 and 2003 we observed another Ortolan Bunting male (ringed in 1999 as an adult), with a repertoire consisting of the typical $a b$ song type and atypical $p b$ and $p$ song types. In that case, $p$ syllables had a very narrow bandwidth and most probably were taken from the local dialect of Redwing Turdus iliacus (Fig. 2). This was the only male with such song types within the population (for years), but this was not an obstacle to attracting a female (probably mated in 2000, and nest found in 2001). Even if in that case the mating success was possible thanks to having a normal song type in the repertoire and undisturbed syntax of songs with foreign elements, we cannot exclude that rare events of vocal mimicry may influence incorporation of new elements into the population repertoire. When atypical song is culturally transferred to the next generation and has normal functionality, it should be treated as a normal one, which has also been shown experimentally in Eurasian Treecreepers Certhia familiaris (Osiejuk \& Kuczyński 2003). The Norwegian population is characterised by a larger syllable repertoire than that of a numerous population from central Europe (Osiejuk et al. 2003a). We may suspect that vocal mimicry in this isolated population may reinforce the process of repertoire enlargement.

\section{ACKNOWLEDGEMENTS}

We thank R. Jahn, H-W. Helb, M. Lang, A. Berg, and A. Frauendorf for providing valuable unpublished information. We are also grateful to S. Ufnalska for improvement of the English. This study was financially supported by the State Committee for Scientific Research (KBN 3 P04C $08325)$.

\section{SAMMENDRAG}

Vi presenterer nye og godt dokumenterte observasjoner av hortulanhanner i Norge med utypisk sang som inkluderte stavelser kopiert fra andre arter og fra fjerne bestander av egen art. Det første tilfellet dreier seg om en hann som sang strofer som inneholdt stavelser fra gulspurv og hortulan, begge deler mest sannsynlig kopiert $\mathrm{i}$ Sentral-Europa. Disse strofene hadde en oppbrutt syntaks. Det andre tilfellet dreier seg om en hann som sang både typiske strofer og strofer hvor den første delen var kopiert fra en lokal dialekt av rødvingetrost, men med typisk syntaks for arten. Denne hannen tiltrakk seg hunn. Årsaker til og konsekvenser av herming av lyder hos hortulan blir diskutert. 


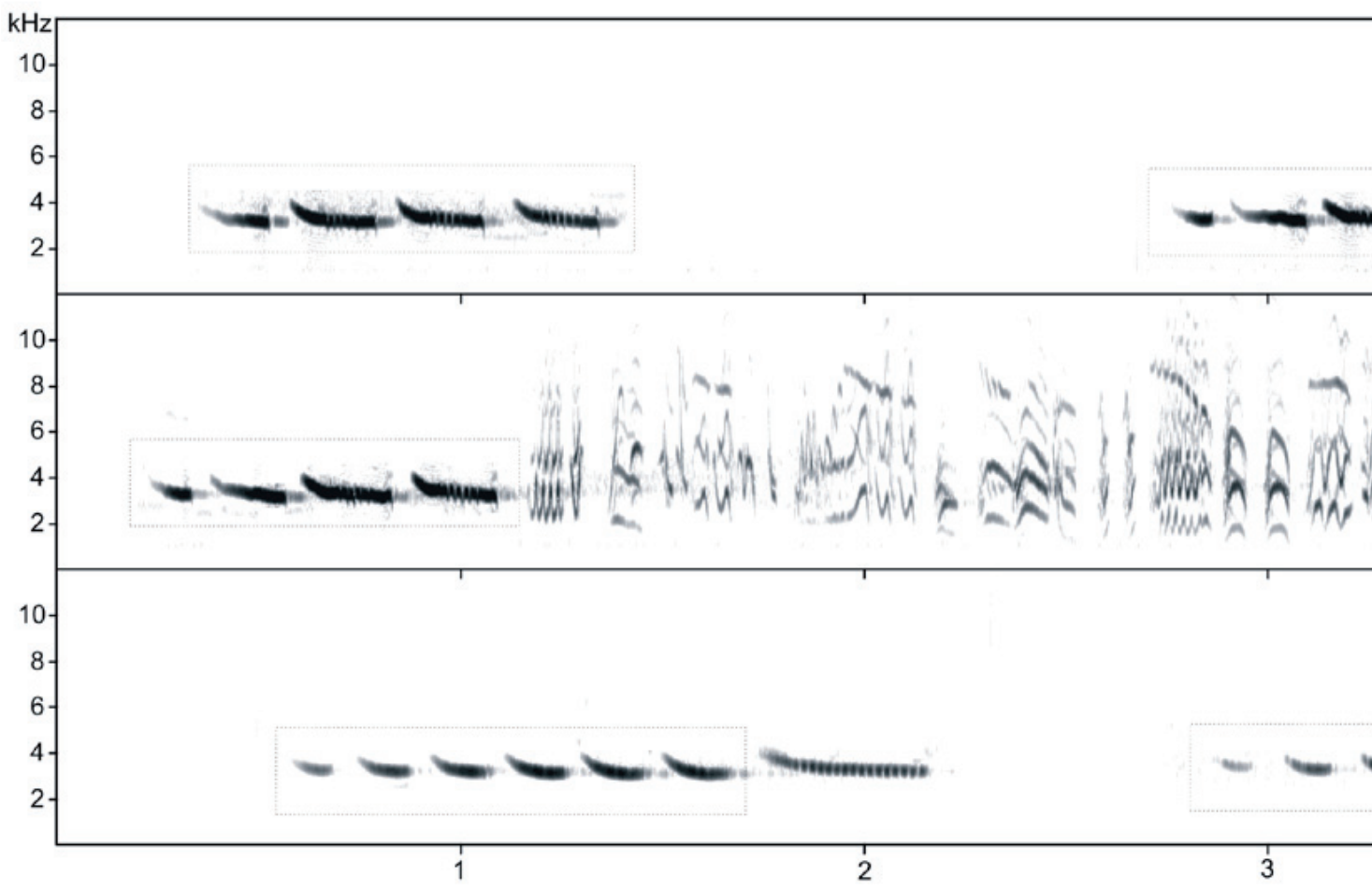

Figure 2. Sonograms of short (a) and full-length (b) song strophes of Redwing. Below (c) two song strophes (type pb and $p$ ) of an Ortolan Bunting male. Rectangles indicate phrases that are acoustically similar and are supposed to be copied by the Ortolan Bunting male from a Redwing tutor. Both species were recorded at the same site (Stornes, $60^{\circ} 38^{\prime} N, 12^{\circ} 16^{\prime} E$ ), but Redwings with such an initial part of song are common in this part of Norway. Note that p syllables are not only similar in shape, but also have roughly the same frequency (Redwing: maximum amplitude at $3.46 \mathrm{kHz}$, frequency range at $-30 \mathrm{~dB}$ threshold 3.17-3.64 kHz; Ortolan Bunting: maximum amplitude at $3.12 \mathrm{kHz}$, frequency range at $-30 \mathrm{~dB}$ threshold $3.08-3.45 \mathrm{kHz}$ ).

\section{REFERENCES}

Åström, G. \& Stolt, B.-O. 1993. Regional song dialects of the Ortolan Bunting Emberiza hortulana L. in Sweden. - Ornis Svecica 3: 1-10.

Baptista, L.F. 1996. Nature and its nurturing in avian vocal development. In: Kroodsma, D.E. \& Miller, E. H. (eds.). Ecology and Evolution of Acoustic Communication in Birds. - Cornell University Press, Ithaca and London, Pp. 39-60.

Baylis, J. R. 1982. Avian mimicry: its function and evolution. In: Kroodsma, D. E. \& Miller, E. H. (eds.). Acoustic Communication in Birds. - Academic Press, New York \& London. Pp. 51-83.

Bremond, J.-C. 1968. Recherche sur la sémantique et les éléments vecteurs d'information dans les signaux acoustiques du rouge-gorge Erithacus rubecula. - Terre Vie 2: 109-220.

Bremond, J.-C. 1976. Species recognition in the song of Bonelli's warbler (Phylloscopus bonelli). - Behaviour 58: 99-116.

Conrads, K. 1994. Dialektenklassen des Ortolans, Emberiza hortulana, im mittleren Europa - eine Übersicht. In: Steiner, H. M. (ed.), I. ORTOLAN-SYMPOSIUM.4.-6. Juli 1992 in Wien. - Institut für Zoologie, Universität für Bodenkultur, Wien. Pp. 5-30.

Cramp, S. \& Perrins, C. M. 1994. Birds of the Western Palearctic: Handbook of the Birds of Europe, the Middle East and North Africa. - Oxford Univ. Press., Oxford Vol. 9. 488 pp.

Dale, S. 2000. The importance of farmland for Ortolan Buntings nesting on peat bogs. - Ornis Fennica 77: 17-25.

Dale, S. 2001a. Causes of population decline of the Ortolan Bunting in Norway. In: Tryjanowski, P., Osiejuk, T. S . \& Kupczyk, M. (eds.) Bunting studies in Europe. - Bogucki Wydawnictwo Naukowe, Poznan. Pp. 33-41.

Dale, S. 2001b. Female-biased dispersal, low female recruitment, unpaired males, and the extinc- 


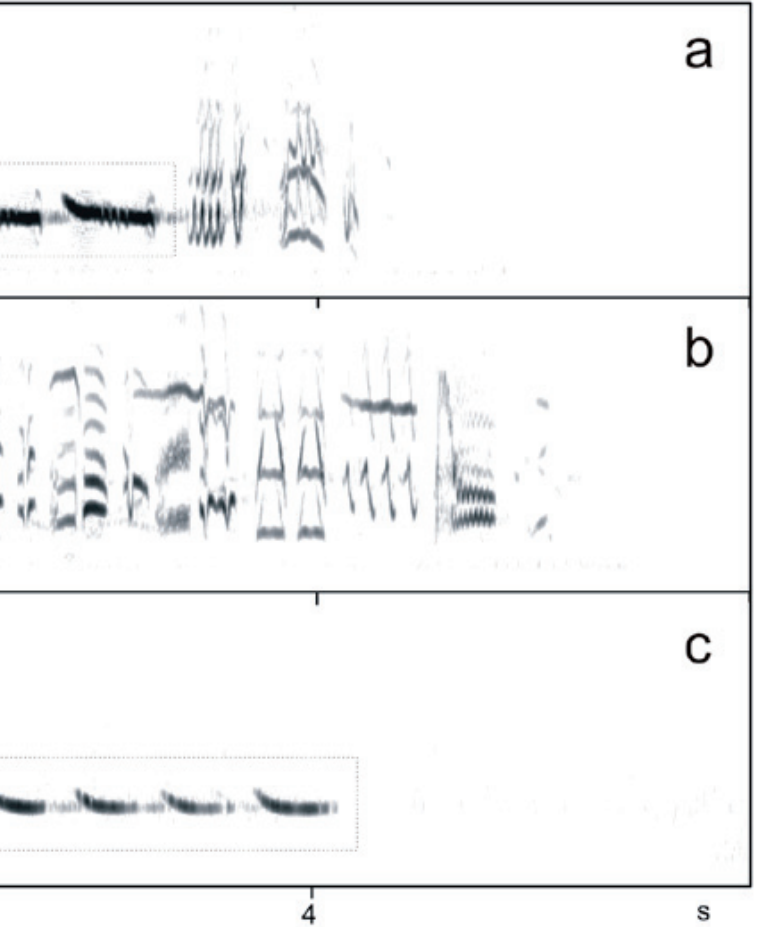

tion of small and isolated bird populations. - Oikos 92: 344-356.

Dale, S. \& Hagen, Ø. 1997. Population size, distribution and habitat choice of the ortolan bunting Emberiza hortulana in Norway. - Fauna Norv. Ser. C Cinclus 20: 93-103.

Dale, S. \& Olsen, B. F. G. 2002. Use of farmland by Ortolan Buntings nesting on a burned forest area. - J. Orn. 143: 133-144.

Frauendorf, E. 1994. Dialekte der Goldammer (Emberiza citrinella) in Ostsachsen. - Actitis 30: $10-28$.

Greenwood, P. J. \& Harvey, P. H. 1982. The natal and breeding dispersal of birds. - Annu. Rev.Ecol. Syst. 13: 1-21.

Hansen, P. 1985. Geographic song variation in the yellowhammer (Emberiza citrinella). - Natura Jutlandica 21: 209-219.

Helb, H-W. 1997. Gesangsdialekte des Ortolans, Emberiza hortulana, in Südeuropa. In: von Bülow, B. (ed.), II. ORTOLAN-SYMPOSIUM. 17.-18. Mai 1996 in Westfalen. - Haltern 1997. Pp. 23-49.

Konishi, M. 1963. The role of auditory feedback in the vocal behavior of the domestic fowl. $-Z$. Tiërpsychol. 20: 349-367.

Konishi, M. 1964. Effects of deafening on song development in two species of juncos. - Condor 66: 85-102.
Osiejuk, T. S. 2000. Recognition of individuals by song, using cross-correlation of sonograms of ortolan buntings Emberiza hortulana. Biol. Bull. Poznań 37: 95-106.

Osiejuk, T. S. \& Kuczyński, L. 2000. Mixed and atypical singers among treecreepers Certhia brachydactyla and $C$. familiaris: a review and preliminary data from western Poland. - Biol. Bull. Poznań 37: 83-94.

Osiejuk, T. S. \& Kuczyński, L. 2003. Response to typical, mixed and shortened song versions in Eurasian treecreepers, Certhia familiaris. - Biologia, Bratislava 58: 985-989.

Osiejuk, T. S, Ratyńska, K., Cygan, J. P. \& Dale, S. 2003a. Song structure and repertoire variation in ortolan bunting (Emberiza hortulana L.) from isolated Norwegian population. - Ann. Zool. Fennici 40: 3-16.

Osiejuk, T. S, Ratyńska, K., Cygan, J. P. \& Dale, S. 2003b. Ortolan Bunting Emberiza hortulana singing like Yellowhammer E. citrinella. - Ornis Fennica 80: 38-42.

Osiejuk, T.S., Ratyńska, K., Cygan, J. P. \& Dale, S. 2004. Frequency shift in homologue syllables of the Ortolan Bunting Emberiza hortulana. - Behav. Proces. In press.

Rutkowska-Guz, J. M. \& Osiejuk, T.S. 2004. Song structure and variation in Yellowhammers Emberiza citrinella from western Poland. - Pol. J. Ecol.52: 327-339.

Stolt, B-O. 1996. The Ortolan Bunting Emberiza hortulana L. in Sweden - migration and abundance. In: von Bülow, B. (ed.), II. ORTOLAN-SYMPOSIUM. 17.-18. Mai 1996 in Westfalen. - Verlag Th. Mann, Gelsenkirchen-Buer. Pp. 101-111. 